Instructions for authors, subscriptions and further details:

http://generos.hipatiapress.com

\title{
Black Women School Leaders: Building Effective Schools Against the Odds
}

Vuyisile Msila ${ }^{1}$

1) University of South Africa

Date of publication: February 25th, 2022

Edition period: February - June 2022

To cite this article: Msila, V. (2022). Black Women School Leaders: Building Effective Schools Against the Odds. Multidisciplinary Journal of Gender Studies, 11(1), 1-23. doi: 10.17583/generos.8925

To link this article: http://dx.doi.org/10.17583/generos.8925

\section{PLEASE SCROLL DOWN FOR ARTICLE}

The terms and conditions of use are related to the Open Journal System and to Creative Commons Attribution License (CC-BY). 
GÉNEROS-Multidisciplinary Journal of Gender Studies Vol. 11 No.1 February 2022 pp. 1-23

\section{Black Women School Leaders: Building Effective Schools Against the Odds}

Vuyisile Msila

University of South Africa

Abstract

Opportunities have been opening for women since the promulgation of the post-apartheid South African Constitution of 1996, which advocates social justice and fairness, including gender and racial equity. However, critics have claimed that women in leadership positions are still a small percentage, hence more transformative initiatives need to be implemented when it comes to gender equity. This case study focuses on black women school leaders in eight secondary schools. It examines the narratives and the leaders' understanding of their roles in leading successful schools. The study explored the roles of black feminism, feminist consciousness and consciousness raising among the women leaders. The major conclusions demonstrate that black women leaders have three factors to address and these are gender, race and culture. The conclusions also reveal that it does not help to single out culture hence a revolutionary lens is critical in this regard. Furthermore, strong women leaders use feminist consciousness, empowerment programmes and pluralistic lens towards social justice, diversity and equity.

Keywords: Black feminism, Feminist consciousness, Effectiveness, Gender inequality, School leadership 


\section{Mujeres negras líderes escolares: Construyendo escuelas efectivas contra todo pronóstico}

Vuyisile Msila

University of South Africa

\section{Resumen}

Se han abierto oportunidades para las mujeres desde la promulgación de la Constitución sudafricana posterior al apartheid de 1996, que aboga por la justicia social y la equidad, incluida la igualdad de género y racial. Sin embargo, los críticos han afirmado que las mujeres que ocupan puestos de liderazgo siguen siendo un pequeño porcentaje, por lo que es necesario poner en marcha más iniciativas transformadoras en lo que respecta a la equidad de género. Este estudio de caso se centra en las líderes escolares negras de ocho escuelas secundarias. Examina las narrativas y la comprensión de las líderes de sus funciones en la dirección de escuelas exitosas. El estudio explora el papel del feminismo negro, la conciencia feminista y la concienciación entre las líderes. Las principales conclusiones demuestran que las líderes negras tienen tres factores que abordar y que son el género, la raza y la cultura. Las conclusiones también revelan que no sirve de nada destacar la cultura, por lo que es fundamental una lente revolucionaria a este respecto. Además, las mujeres líderes fuertes utilizan la conciencia feminista, los programas de empoderamiento y una mirada pluralista hacia la justicia social, la diversidad y la equidad.

Palabras clave: Feminismo negro, Conciencia feminista, Eficacia, Desigualdad de género, Liderazgo escolar. 


\section{Msila-Black Women School Leaders}

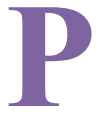

hakeng (2015) writes of how African women become invisible because of the dominance of patriarchal values as well as class and race. Furthermore, Phakeng (2015) points out that the chances of black women assuming leadership positions are almost nil, and their invisibility is very pronounced. Although governments and corporates around the world have tried to accommodate women, this has not always been successful because gender bias tends to thwart their efforts. Connley (2020) argues that women in corporate America face gender discrimination in the workplace and this is even more if you are a black woman because challenges are compounded by hindrances associated with racism. Like Phakeng (2015) above, Connley (2020) points out that various ways have been tried to boost women's involvement in leadership, but diversity and inclusion efforts have failed to make any real difference. Furthermore, Morgan (2020) also points out that in Britain, despite the increasing initiatives to enhance diverse leadership workplace profiles, there are still a very low number of black women in positions of power. Black women can usually be found in leadership positions only in workplaces that encompass cultural, racial and gender biases. Whilst it is true that white women leaders also face challenges in workplaces, racism and sexism remain more significant obstacles for black women (Connley, 2020). As in various other workplaces, black women leaders experience countless obstacles in schools globally. Burton, Cyr and Weiner (2020) accentuate the need for research that encourages anti-racist and anti-patriarchal tendencies. In many instances, black women school principals are placed in underperforming schools where they may be likely to fail. Burton et al. (2020:2) state:

Jean-Marie's (2013) work about Black female principals found her participants, like many Black female school leaders, were placed in low performing schools and pigeonholed as "fixers" (Brown, 2005; McCray et al., 2007). In addition, they faced the "triple jeopardy" of gender racism and ageism by those they supervised, parents and community members, and their superintendents. They also experienced subtle biting comments about their capabilities to be successful and had to engage in additional work to access their leadership positions.

As a result of numerous obstacles, some black women leaders may not be successful as leaders and, as they flounder, they may fail alone because there are few or no people to lean on for advice and mentoring (Rosette \& Livingston, 2012). In many instances, black women leaders must make 

11(1)

meaning of their leadership as they plod along. Usually these leaders become resilient to the circumstances they are exposed to. Foster (2021) states that black women leaders are likely to utilise coping strategies to shield themselves against several obstacles such as humiliation, marginalisation and frustration. Foster also points out that women leaders who form support structures for mentoring and sustenance are likely to be strong and may succeed as leaders. De Bruyn and Mestry (2020) claim that women school principals who have been prepared theoretically, practically and psychologically are likely to be successful in their principalship positions. De Bruyn and Mestry (2020) also suggest a resilience framework that includes tangible support for in-service principals to enable them to deal with everyday challenges.

This study explores the contexts in which the black woman school principal works. It is always interesting to examine what makes the male leader different from the female leader. It is also crucial to examine the concept of race when one explores gender and leadership. The questions posed in the study were:

- How do leadership, race and gender matter in historically black schools in South Africa?

- In which ways can black women school leaders overcome the beliefs set by the dominant society?

\section{Black women and the politics of gender}

bell hooks (1995) highlights the importance of examining the struggle for women to embrace conscious raising or critical consciousness when it comes to understanding feminist thought. Critical consciousness means that women should use the paradigms of sex, race and class within which they should work towards identity recognition. Wilcox (1990) states that, because women are disadvantaged based on race and gender, this has led to a greater racial group consciousness and mobilisation among them. Various writers have argued that feminist consciousness could enhance the quality of life for not only black women but also black men as well (Wilcox, 1990; hooks 1995; Kinnear \& Ortlepp, 2016). Women need to redefine their feminist notions as they gain power (Kinnear \& Ortlepp, 2016). Furthermore, Wilcox cites Klein who points out that women who embrace feminist consciousness go through three steps, namely; (i) recognising their membership within a group, (ii) blaming 


\section{$5 \quad$ Msila-Black Women School Leaders}

the system for the disadvantages they experience and (iii) recognising the need for collective action to end the disadvantage. Kellard (2020) and Batliwala (2010) postulate that feminist consciousness should help raise women to speak out against injustices to lessen women's challenges and contemporary feminists can help do this.

hooks (1995:329) writes about the politics of gender and feminism when she opines that we live in a world governed by the politics of domination "one in which there is the belief in a notion of superior and inferior and its concomitant ideology - that the superior should rule over the inferior." Additionally, hooks goes on to claim that, unlike the proclamation of Western feminists, patriarchal domination is not the only challenge for black women in society. Biana (2020) cites hooks as she states that there is a need for a revolutionary feminist outlook, which utilises a pluralistic lens to appreciate the absence of oppressed groups as well as to undertake a close examination of cultural representations. There is also a necessity to resist racism and other forms of domination. hooks (1995) has reservations about merely showing that man is the foe and the woman the victim. She also argues that black women should not support this fallacy for black men are as oppressed as they are. hooks (1995:330) also contends:

As significant and important as this fact is, it should not obscure the reality that women can and do participate in politics of domination, as perpetrators as well as victims - that we dominate and we are dominated. If focus on patriarchal domination masks this reality...then women cooperate in suppressing and promoting false consciousness, inhibiting our capacity to assume responsibility for transforming ourselves and society.

Black women encounter patriarchal domination every day, but they should always be aware of the role of gender, race and class as well. The women's struggles in society should be against all forms of domination. Therefore, there is a need to see feminism as a liberation struggle, which should strive to end all forms of oppression. Furthermore, patriarchy can never end whilst various other forms of domination exist. For hooks (1995), defining feminism should imply sharing a political goal. For the attainment of this political goal, it is critical for women to use small groups to achieve education for critical consciousness. The rise of feminist thought means there is a demand for empowered women who would assume the positions of power. Feminist consciousness, according to hooks, refers to women liberation and opening paths towards gender equity and social justice. In addition to this, Henry 

11(1)

(2005) contends that black women need a black feminism, a concept that he finds useful in black women leadership. Henry (2005:2) explains:

Patricia Hill Collins (1991) argues that Black feminism is a "process of selfconscious struggle that empowers women and men to actualize a humanist vision of community" (p. 39). Importantly, she emphasizes that, "In spite of the fact that Black women do not readily identify themselves as feminists, there is a high level of support for feminist issues" (Collins, 1991, p. 153). Barbara Omolade notes (1994) that "Black feminism is sometimes referred to as womanism because both are concerned with the struggles against sexism and racism by Black women who are themselves part of the community's efforts to achieve equity and liberty."

Much literature shows that black feminism shapes the development of black women leaders (Rosser-Mims, 2010; Sylvester, 2019). Furthermore, RosserMims (2010:2) maintains that black feminism can help women be the guiding force "in leading the black community out of subjugation to a greater educational, political, and ideological self-empowerment". Sylvester (2019) highlights the significance of women's voices that ought to be heard as women reflect on their leadership practice. When women assume this voice, they can dispel the myths of their ineffectiveness and weak leadership stereotypes. Myeza and April (2021:1) use black psychology to analyse black leadership. These two writers state that black professionals in general exhibit signs of pain, anger and emotional fatigue emanating from workplace, socio-economic and "political triggers that evoked generational trauma and overall negative black lived experiences". The history of oppression or the story of apartheid in South Africa plays a negative role in the development of all black professionals. As Myeza and April (2021:1) point out, "black professionals were found to display symptoms of 'survivor guilt', stemming from the shared history of oppression among black people in South Africa." The problem with black women is that within and outside their own communities, they might not be expected to be leaders. This is what Myeza and April refer to as Atypical Leaders. Rosette and Livingston (2012) also point out that black women leaders suffered what they referred to as double jeopardy and were judged more negatively than black men and white women under the circumstances of organisational failure. Black women have the dual subordinate identities of being black and being women (Rosette \& Livingston, 2012). This double jeopardy also supports the idea that white leaders are more 


\section{Msila-Black Women School Leaders}

professional and stronger as leaders than blacks and black men are far better than black women (Burton \& Weiner, 2016; Foster, 2021).

\section{Research methodology}

This qualitative study was conducted in eight schools in four South African provinces, namely, Eastern Cape, Gauteng, KwaZulu-Natal and Mpumalanga. Therefore, in each province two principals were interviewed. For decades principals in South Africa had been appointed to lead schools as a result of their excellent classroom practice. In fact, in several countries a teaching qualification and teaching experience were the only requirements for school principalship (Bush, Kiggundu \& Moorosi, 2011). All the eight principals in the study had gone through the Advanced Certificate in Education - School Management and Leadership (ACE-SML) qualification which was first piloted in six South African provinces in 2007. The ACE -SML qualification was the first two-year formal qualification in South Africa which prepared practising principals as well as future principals with the necessary leadership and management skills. Initially, in each province the principals were interviewed individually before using focus group interview through zoom to discuss with all eight. Purposive sampling was used to select the principals; all were black women; they had been school principals for at least four years, and all were leading high schools or secondary schools. Purposive sampling is useful when wanting to use information-rich cases related to a phenomenon of interest (Palinkas et al., 2015). Brink (2000) points out that purposive sampling is based on the judgement of the researcher regarding participants who are representative of the topic being studied. In this study, the researcher sought black school principals who had a work experience of at least four years or more as principals and people with rich information about black women leadership. All were principals in historically black schools; these are schools that were meant for black families under apartheid. Years after the outlawing of apartheid education these schools remain with 100 percent black learners.

Data analysis in this study made use of the data presented in the form of words. I examined the transcripts searching for similarities and differences, subsequently finding themes and developing categories. I manually separated and categorised the data. I had to reduce the voluminous data by subdividing it using coloured pens to categorise it. Therefore, I created the categories, did the coding, decided what needed to be collated and then identified the patterns to draw meaning from the data (Wong, 2008). The last step after reviewing, 

11(1)

exploring and creating initial codes was to revise the codes and combine them into themes before presenting the themes in a clearly elucidated manner. The participants had the opportunity to see and read their transcripts to verify their responses. Anonymity was assured and the recorded zoom meeting was not to be viewed by anyone besides myself as the researcher. Below are the characteristics of the participants:

Table 1

Characteristics of the sampled women leaders $P=$ Participant; EC-Eastern Cape; KZ-KwaZulu Natal; G-Gauteng; MP-Mpumalanga

\begin{tabular}{lcllll}
\hline & Age & $\begin{array}{l}\text { Years of } \\
\text { experience } \\
\text { as principal }\end{array}$ & $\begin{array}{l}\text { Nature of } \\
\text { school }\end{array}$ & $\begin{array}{l}\text { Female } \\
\text { Staff }\end{array}$ & $\begin{array}{l}\text { ACE-SML } \\
\text { qualification was } \\
\text { completed }\end{array}$ \\
\hline $\begin{array}{l}\text { PEC } \\
\text { 1 }\end{array}$ & 38 & 4 years & $\begin{array}{l}\text { Rural } \\
\text { school }\end{array}$ & $48 \%$ & 2015 \\
PEC2 & 45 & 7 years & $\begin{array}{l}\text { Urban } \\
\text { school }\end{array}$ & $54 \%$ & 2011 \\
PKZ1 & 47 & 5 years & $\begin{array}{l}\text { Rural } \\
\text { school }\end{array}$ & $39 \%$ & 2009 \\
PKZ2 & 41 & 8 years & $\begin{array}{l}\text { Urban } \\
\text { school }\end{array}$ & $30 \%$ & 2011 \\
PG1 & 53 & 5 years & $\begin{array}{l}\text { Urban } \\
\text { school }\end{array}$ & $52 \%$ & 2013 \\
PG2 & 48 & 7 years & $\begin{array}{l}\text { Urban } \\
\text { school }\end{array}$ & $50 \%$ & 2009 \\
PMP1 & 40 & 3 years & $\begin{array}{l}\text { Rural } \\
\text { school }\end{array}$ & $45 \%$ & 2013 \\
PMP2 & 49 & 4 years & $\begin{array}{l}\text { Urban } \\
\text { school }\end{array}$ & $53 \%$ & 2011 \\
\hline
\end{tabular}

For the interviews I used an interview guide or interview script that was prepared for both individual and focus groups. The questions were all tied to the purpose of the study. To ensure that I focus on relevant themes, semistructured questions were grouped under four themes; (i) Women and feminist consciousness, (ii) Feminism and leadership styles, (iii) Society, power and leadership styles, and (iv) Race, gender and leadership. Dejonckheere and Vaughn (2019) point out that when using semi-structured interviews, 


\section{Msila-Black Women School Leaders}

researchers can collect open-ended data as they explore participant thoughts, feelings and beliefs. During this process the researcher is also able to dig deep into personal and sensitive issues.

\section{Results}

Whilst the eight participants differed in a few aspects because of their ages and experience, they shared countless qualities as leaders. Their struggles as black women in historically black schools made them learn to be resilient and lead under the most trying of times. There were several obstacles that they had to endure like being respectful and understanding their communities' cultures. Three participants - one from each of the provinces excluding Gauteng - were from rural areas. Yet all participants contended that besides the culture of patriarchy there were other challenges posed by the society on women leaders. However, all of them posited that leadership should not overemphasise gender because there are weak women leaders as there are weak male leaders. They also reiterated how the content of the ACE-SML qualification assisted them in using "international theories" to empower themselves as effective school leaders. Initially, they found leading "big schools" daunting, but they soon discovered that all meticulous leaders irrespective of gender and race learn over time. The participants also concurred that South Africa, since achieving freedom in 1994, has opened several human rights to all citizens. Equity is part of social justice enshrined in the Constitution of the Republic but gender oppression and undermining of women leaders by both men and women still pervade organisations. PEC 1 (Participant Eastern Cape 1) appeared to summarise what others pointed out when she said:

I think we have many opportunities as women now. When I was interviewed for this position, I competed with two men and I won. The system is giving us opportunities. I am certain that like a few other women leaders, I was well-prepared by my district officials and I felt empowered before I started. Yet, the problem was arriving at a school where the staff was not prepared for a woman principal. I was black, I was young and I am a woman who is not originally from the vicinity of the school. 

11(1)

PKZ2 (Participant KwaZulu-Natal 2) shared some of these sentiments when she stated:

Two factors really hit me hard at the school when I arrived. Firstly, the school was $80 \%$ male. The few women at the school were rather quiet almost subservient for most of the time. They were inward looking. Not verbal at all. Secondly, the school had ingrained cultures, male cultures if I can be frank. Even the jokes in the staffroom were very chauvinistic but this was normal in the language of the school. Mine has been a long journey as a black woman school leader.

Six of the eight principals agreed that there are still many challenges for black women leaders because they assume duties at schools still bound by society's 'old' values. Furthermore, they dispelled the myth that males are better leaders because of certain qualities for they maintained that effective leaders have a variety of qualities and gender does not determine who will be an effective leader. Two maintained that male leaders are stronger because they are "born with certain leadership qualities", yet many of the participants restated that today's organisations are challenging for all leaders. Technology is transforming organisations and bringing new challenges for everyone irrespective of gender. In addition, as one participant put it, "it is leaders who are creative who will survive the current challenges in organisations". Much research done has delineated major differences between male leadership styles and female leadership styles with each gender differentiated by its strengths and weaknesses. PG2 (Participant Gauteng 2) pointed out that:

I do not think women can hide behind the disadvantage of gender. I think we are still striving to level the playing fields, but our male counterparts are exposed to the same challenges today.

PG1 echoed the same:

You see the schools and organisations today need eclectic approaches. You can use neither absolute female styles nor absolute male styles, if these are existent anyway. In schools, you encounter so many situations that need varying styles. We cannot depend on being soft or hard in leadership. Many a times we need to use 


\section{Msila-Black Women School Leaders}

traditional female approaches, sometimes traditional male styles. Women are not stuck in (the) same styles.

PKZ1 also pointed out:

Sometimes people would condescend women by stating that we are soft and very good for organisations. No, but I would like to point out two things; on the one hand we are females and have certain innate qualities that men do not have. This help and many a times make us stronger leaders. On the other hand, though, we must agree that there are many qualities we share with our male counterparts.

PMP1 (Participant Mpumalanga 1) concurred with the above:

I have to say that opportunities again are now for everybody. As a woman, I can fight for any position and get it if fairness prevails. My school is situated in a rural part of Mpumalanga where I have witnessed much patriarchy. Patriarchy is sometimes the hindrance. Male colleagues look at women leaders with suspicion. I do not regard myself a feminist but I do support some feminist principles. Black women leaders need to constantly meet and equip one another. I normally travel to Mbombela, our province's capital, to meet other women leaders. It helps.

PG2 also supported the above when she stated:

It always helps meeting other black women principals. We have established a small group of ten principals in my area and we have black women principals from primary schools and high schools. This group helps. We become stronger every day and I believe this is the only way that black women leaders can overcome the obstacles brought by gender, culture and race in our schools. All school have challenges but those led by black women can be more disheartening because of the different view society looks at black women leaders.

The participants contended that many women, even when they are effective leaders at school, may be treated differently, and not acknowledged as leaders outside their schools. PEC1 referred to this, as "double living" where one is not as strong at home, as one is at school if one is an effective leader. She said, 

11(1)

"Culture and tradition muffle the leadership abilities and you might find that at home you need to portray the culturally accepted notions of womanhood".

Four of the participants pointed out, though, that they came from households that understood their roles as leaders in the workplace and described how they balanced that with their roles when they get home.

The participants also talked expansively on the need to build resilient roleplayers at their schools. PKZ1 shared her experience about how she facilitates resilience among her teachers, especially female teachers, because in her rural school there was a tendency for masculinity to dominate in the way the school is run. Whilst she expected males to be resilient because of the learners coming from poor families with various challenges, she focused more on women teachers who were under pressure from the community and from learners, as well as from the School Governing Body (SGB), which was not always supportive.

Generally, for the participants what was critical in their schools was the creation of a culture and a climate that "includes rather than excludes" (PG1). This refers to not only to gender but race as well. For the participants when the school culture excludes it leads to a climate that is sexist built on societal stereotypes. PG2 and PKZ1 explained that it is critical to portray the school's gender policy through the climate. PKZ2 and PMP2 also added that some of these policies could be seen through other role-players such as parents and learners. PKZ1 declared:

Our school's climate reflects the school's policies. The attitudes and behaviours in the school are reflected by the role-players as you enter the school and observe its climate. Many behaviours tell you about the school before you even talk to any of the members. Parents walking to my office get the feel of the climate just by observing.

PMP1 echoed some of these sentiments when she talked about school culture:

My school has that sense of a school climate where you can see the attitudes and behaviours in the school climate. But many of the challenges are in the school culture where it is sometimes evident that there are duties where you would not find collaboration. The beliefs staff use are still based on women's job and male's 


\section{Msila-Black Women School Leaders}

responsibility. In the staffroom, there will always be jokes about women responsibilities and men responsibilities. Usually these are uttered in jest, but one easily sees that this is ingrained in beliefs and these manifest in school culture.

In the focus group, the participants expressed themselves more about the need for not only women but all leaders to be continuous learners. All the participants shared how they were all trained in a very patriarchal system of education in their initial teacher education programmes and now they had to actively improve their qualifications by learning and relearning new approaches. They all spoke highly of the ACE-SML qualification which they found empowering although they maintained that there should be more gendered courses in the programme. The debate that was advanced by the participants was that when principals have the right skills they cannot be intimidated by any negative cultures. They also pointed out that women leaders today, despite some vestiges of struggles with tradition and stereotypes, when empowered they know how to act. They pointed out growing up in a society that "Others women" had made many grow up believing that men are superior hence many women constantly compare themselves to men. In this regard, PG1 opined:

When I became a head of department in my previous school, I freaked at the idea of leading men initially. This was before my ACESML involvement. I wanted to lead like male colleagues. I wanted to be an exact copy of males I have come across in my career. But then now I am matured. I know I can be myself and still be an effective leader. If all of us could be prepared, we will know the battle against race, class and culture is half-won.

The participants spelt out that being women is only half the challenge because being black is another huge problem. In focus group they expressed how the role-players such as communities and SGB might doubt their abilities to lead high performing schools. The principals in the rural schools especially, share how communities frequently express mistrust about their ability to lead the schools. PKZ2 succinctly expressed this:

For me it is a racial thing. The communities see us as not only women leaders but as black women. They know how culture expects black women to be in a patriarchal society. In many black cultures, male 

11(1)

roles and female roles are different. Women usually follow and are rarely leaders. But this is where we need to change society because the same people may think differently if a white woman is at the helm of an organisation. As black women we need to change our world.

The need to relearn was reiterated by the participants. Seven of the principals stated that their schools could do much better in learner achievement. However, they pointed out they struggled because generally many historically black schools still struggled from the past anomalies of education inequities and there has been little culture of teaching and learning. They also affirmed that black women leaders would lead high performing schools if they stand strong despite societal stereotypes as they lead successful schools which make positive impact on surrounding communities. The participants also concurred that there were crucial women attributes that support empowered women such as mothering, loyalty and collaboration. However, they also pointed out these are qualities that men leaders also need hence dynamic leaders will display an array of qualities which are not necessarily following the social stereotypes. PMP1 for example pointed out how her district director told her to be strong and "act like a man because staff responds well to principals who are assertive and bold".

Whilst almost all the participants talked about opportunities that are opening for women in leadership, they also pointed out that black cultural practices can be a hindrance to women advancement. The experience of insubordination from male colleagues is sometimes justified by cultural practices. In some cultures, there is gender inequality, and this frequently shows in institutions such as schools. The participants added that although not always very apparent, male colleagues can covertly use culture to undermine the leader's initiatives. The gender inequity that women leaders highlight makes them use strategies to be resilient in the face of male domination. Additionally, some men can use cultural practices and beliefs as reasons for being insubordinate to women leaders. Therefore, this shows that schools are not insular from community beliefs. The male insubordination and the justification from cultural practices were more pronounced in rural schools although this was also evident in urban schools as well. The principals from the rural schools echoed how they found subtle opposition from even the SGBs who tended to support the overt and covert traditional "masculine ways" of running the schools. 


\section{Msila-Black Women School Leaders}

The focus group discussions raised a few critical points as the participants focused more on solutions. Among the major aspects brought forward were the constant need to learn from one another and avoid the tendency of women working alone as highlighted by Rosette and Livingston (2012) above. They also pointed out that programmes such as the ACE-SML should be refined to support women leadership because the ACE-SML programme assisted them psychologically to face some of the challenges of leading schools. They also stated that women need to use the feminist consciousness to be able to build conscious raising as well as critical consciousness that hooks (1995) discusses. The participants also concurred that it is when women learn to stand against injustices in school meetings that they may be able to influence culture that oppresses. Furthermore, they stated that women leaders can work towards just schools by conscientizing male colleagues and female colleagues. Many colleagues are products of an oppressive culture that has taught them that women are inferior. The participants also reiterated that society needs to move beyond the idea that blackness is equivalent to underperformance. Conscientious leaders will succeed whether they are white or black and whether they are male or female. Finally, the eight participants shared a list of words that they found common in running high performing schools where learners achieve and they reiterated these during the interviews: cooperation, shared leadership, trust, communication and being able to be an adept conflict manager. Although they highlighted that it may be paradoxical to expect the women principals to trust society for support, they pointed out that, like all other school leaders, they depended upon strong links with the communities. They also underscored the need to have functional SGBs that would support change initiatives within the schools.

\section{Discussion}

\section{Feminist consciousness notions and effective leadership}

The participants highlighted how, as black women, they needed to learn from one another as they developed their leadership capacity. This idea is very close to the consciousness raising that feminists such as bell hooks (1995) talk about in their feminist theory. It is critical for black women leaders to develop an awareness of what is working and enhances leadership effectiveness (Sylvester, 2019). Henry (2005) contends that women do not need to be feminists to apply the feminist principles. In fact, when the black women leaders meet, they may reflect on what constitutes effectiveness and how to 

11(1)

achieve it. Effective leadership refers to leadership that supports diversity as it embraces social justice. Lumby (2013) cautions that as society we should be wary of leadership theories that are apolitical and are replete with uses and abuses of power. Lumby (2013) argues that distributed leadership for example tends to be apolitical and supports the status quo. Msila (2008) writes about African models of leadership based on the philosophy of Ubuntu, I am Because You Are. Ubuntu is purported to be successful because employees depend on one another for organisational success.

The participants talked about being resilient to oppose anti-women power. This is in line with what De Bruyn and Mestry (2020) underscore in their study when they opine that resilience is necessary to deal with everyday challenges by women leaders who seek success. In fact, in this study the participants found resilience to be part of consciousness-raising for liberating the leader towards achieving just and effective leadership.

Effective leadership depends more on the relevant qualities of leaders and the participants in this study maintained that qualities such as motherhood, flexibility, loyalty mentoring and collaborative leadership were among the qualities that were common among women leaders. They believed that all women leaders are likely to have these qualities although today women leaders will go beyond nurturing and mothering. The belief that women are more nurturing than men has led research to regard them as more transformational than transactional. Literature points out that transformational leadership underscores nurturance of followers and women have the relevant qualities for this nurturing function. However, Pounder and Coleman (2002) contend that today's organisations have become very dynamic and need more multidimensional models of leadership. They argue that modern leaders need must play numerous complementary roles and both male and female leaders can be effective according to this model. Therefore, as evident in this study, visionary leaders will not merely display male or female qualities of leadership, but they will be androgynous, a term that explains the combination of both female and male leadership traits. Therefore, to be an effective leader does not depend on whether you can use female or male characteristics of leadership but on being able to use them both under different circumstances. Zenger and Folkman (2012) have shown that women are better in many leadership categories, which include initiative, resilience, developing others and leading change. 


\section{Msila-Black Women School Leaders}

\section{The conundrum of patriarchy and women's resilience}

Batliwala (2010) cites Antrobus (1999) who maintains that patriarchy dehumanises men as it denies women their humanity. Carbajal (2018) writes about how the patriarchal culture thwarts the women's growth in leadership positions. Furthermore, Carbajal (2018:1) posits that some men in the schools do not show empathy to and support for women leaders and they may still not see them as equal to men leaders. The patriarchal culture frequently emphasises gender inequality and this is an unjust culturally accepted norm, which leads to cognitive bias of categorisation or othering of women. In the study women talked about how they are demeaned by patriarchy even when they do their best to show their worthy leadership qualities. Usually, the patriarchal society expects women leaders to act like men and this gender bias demeans women's worth as leaders.

Effective women leaders will be those who refuse to internalise social stereotypes. Women have frequently been portrayed as weak and incapable of making smart decisions (Komath, 2014). However, Komath points out that now trends are changing as there is growing awareness of women as effective leaders in society and the fights for social justice have included attacks on patriarchal attitudes all over the world (Komath, 2014).

Like male leaders, women need several strategies to cope as leaders. In the study, the participants maintained that it was critical for women leaders to strengthen their feminist values in order to survive in patriarchal organisations. The participants demonstrated the strength of learning that enhances feminist values, leading them to engage in the bigger struggles against social injustice in society. Feminist values can be a catalyst towards transformational leadership and a revolution in school leadership, as we know it traditionally. "Feminist values argue for replacing hierarchical authority with participatory decision-making. This does not imply structurelessness, but structure that is democratic" (Schniedewind, 1987:172). In the focus group discussions, the participants emphasised how their leadership needed to influence not only the school role-players but also the communities where the schools are situated. They regarded their positions as well placed to promote collaboration, shared leadership and shared governance in the school. The participants realised they had a huge role to play in society to convince the community of their ability to change the schools for the better. The participants described their adherence to feminist leadership strategies. All the participants believed in participative interactive leadership with several them 
talking about Ubuntu leadership in their schools. As briefly explained above, Ubuntu is a philosophy based on African heritage, which can be summarised by the truism, "I am because you are". Like some elements of servant leadership, the Ubuntu philosophy is based on qualities such as trust, solidarity, dependability, community and communication. The participants used these values to effect meaningful changes in their leadership practice.

Batliwala (2010) defines feminist leadership as the kind of leadership that that seeks to highlight women's talents to address major social and political concerns. Batliwala (2010:10) cites Barton (2006) who points out that feminist leadership uses a feminist lens "to identify injustices and oppressions and inspires her to facilitate the development of more inclusive, holistic communities. Feminist leaders are motivated by fairness, justice, and equity and strive to keep issues of gender, race, social class, sexual orientation and ability at the forefront". Feminist leadership is thus an antidote to patriarchy.

\section{Blackness - What's race got to do with leadership?}

For decades the traditional high school principal in South Africa has been male in many historically black schools. In fact, several writers have shown how black women under apartheid suffered because of their gender and secondly because of their race hence they referred to their oppression as double suffering (Unterhalter,1990). Much research on black women leaders tends to focus on social stereotypes based on patriarchy, culture and gender rather than race and power. Yet the suffering of black women leaders continues to be underscored by their blackness as well. As highlighted in the Rossete and Livingston (2012) study above, three factors make black women atypical leaders, and these are race, gender and failure. It is inadequate to focus on patriarchy for black women leaders without looking at various ways to liberate themselves as black women who have a history of oppression under colonial and apartheid dispensation. The preparation programmes for black leaders need to examine black psychology and ways of overcoming ingrained societal beliefs when it comes to leadership.

Myeza and April (2021) write about the importance of using the black experience when it comes to the emergence of black leaders. Black women leaders also need to understand the intersectional frame because the sexism and racism are not discrete experiences. Burton et al. (2020:2) cite Collins who points out that intersectionality "provides critical insight that race, ethnicity and other identities operate as a reciprocally constructing 


\section{Msila-Black Women School Leaders}

phenomena that in turn shape social inequities." Additionally, learning about race and identity is critical for all South Africans as they prepare themselves for racially diverse environments. The black feminists usually see reality differently as Phakeng (2015:1) puts it, "Feminism among Africans has also not fared well, because of its epistemological whiteness which, understandably, has not had much purchase in South Africa. Feminism therefore often sets up a rivalry between black and white women, because it has generally been soft on racial and class inequality."

\section{Conclusion}

In the final analysis, in line with existing research the study demonstrated that factors such as gender and culture will always matter in schools. Yet we can never leave out race when we discuss black women leaders in South Africa. They intersect and discussions on leadership will be hollow when we do not examine the dynamics of race and power. In creating effective, high performing schools, black women leaders, like all other leaders need constant empowerment programmes. The ACE-SML was one such example in this study. Empowerment means that leaders may always be aware of obstacles as they use pluralistic lens to focus on cultural representations. Furthermore, female leaders in addition to the formation of professional networks and mentoring programmes they need to embrace the feminist consciousness which would lead to social justice and equity. In fact, it will be black women leaders who have a wide range of qualities who will be strong and effective leaders.

Finally, it would also have been interesting to study black women principals who lead racially mixed staff to understand other dynamics that might be at play. Other future studies that explore these themes might also have to include more participants, especially diverse school management teams, to see how the teachers view the black woman school leader. More studies also need to be conducted using the revolutionary feminist lens of black feminists such as that of hooks (1995) to see the broader theories of feminism, including indigenous feminism which did not form part of this study. 

11(1)

\section{References}

Batliwala, S. (2010). Feminist Leadership for Social Transformation: Clearing the Conceptual Cloud. New Delhi: CREA.

Biana, H.T. (2020). Extending bell hooks' Feminist Theory. Journal of International Women's Studies, 21(1), 13-29. https://vc.bridgew.edu/jiws/vol21/iss1/3

Brink, H. (2000). Fundamentals of Research Methodology for Health Care Professionals. Juta.

Carbajal, J. (2018). Patriarchal Culture's Influence on Women's Leadership Ascendancy. The Journal of Faith, Education, and Community, 2(1). https://scholarworks.sfasu.edu/cgi/viewcontent.cgi?article=1011\&conte $\mathrm{xt}=\mathrm{jfec}$

Burton, L.J. \& Weiner, J.M. (2016). "They Were Really Looking for a male leader for the Building": Gender, Identity and Leadership Development in a principal Preparation Program. Frontiers in Psychology, 7, 141. https://doi.org/10.3389/fpsyg.2016.00141

Burton, L.J., Cyr, D. \& Weiner, J.M. (2020). Unbroken, but Bent: Gendered Racism in School Leadership. Frontiers Education, 5, 52. https://10.3389/feduc.2020.00052

Bush, T., Kiggundu, E. \& Moorosi, P. (2011). Preparing New Principals in South Africa: The ACE School Leadership Programme. South African Journal of Education, 31(1): 31-43. https://doi.org/ 10.15700/saje.v31n1a356

Connley, C. (2020). How Corporate America's Diversity Initiatives Continue to Fail Black Women. https://www.cnbc.com/2020/07/01/howcorporate-americas-diversity-initiatives-continue-to-fail-blackwomen.html

De Bruyn, N. \& Mestry, R. (2020). Voices of Resilience: Female School Principals, Leadership Skills, and Decision-making Techniques. South African Journal of Education, 40(3). https://10.15700/saje.v4n3a1757

DeJonckheere, M. \& Vaughn, L. (2019). Semistructured Interviewing in Primary Care Research: A Balance of Relationship and Rigour. Family Medicine and Community Health, 7(2). https://10.1136/fmch-2018000057

Foster, O.S.G. (2021). A Phenomenological Exploration of the Leadership Development Experiences of Black Women. Walden University. 


\section{Msila-Black Women School Leaders}

Henry, A. (2005). Black Protest Thought and Education, Counterpoints, 237, 89-105.

hooks, b. (1995). Feminism: A Transformational Politic. In F.L. Hord, \& J.S. Lee (Eds.), I Am Because We Are (pp. 329-337). University of Massachusetts Press.

Kellard, L. (2020). A Call to Arms: The Centrality of Feminist Consciousnessraising Speak-outs to the Recovery of Rape Survivors. Hypatia, 31(4), 730-745. https://doi.org/10.1111/hypa.12295

Khumalo, S.S. (2021). Analysing the Experiences of Women Principals in Primary Schools in Limpopo Province, South Africa through Social Justice Theory. Problems of Education in the $21^{\text {st }}$ Century, 79(1), 47-59. https://doi.org/10.33225/pec/21.79.47

Kinnear, L. \& Ortlepp, K. (2016). Emerging Models of Power among South African Women Business Leaders. SA Journal of Industrial Psychology, 42(1). http://dx.doi.org/10/4102/sajip.v42i1.1359

Komath, A. (2014). The Patriarchal Barrier to Women in Politics. iKNOWPOLITICS https:/www.iknowpolitics.org/en/knowledgelibrary/opinion-pieces/patriarchal-barrier-women-politics

Lumby, J. (2013). Distributed Leadership: The Uses and Abuses of Power. Education, Management, Administration and Leadership, 41(5):581597 https://doi.org/10.1177/1741143213489288

Mnisi, C.T. (2015). Female Primary School Leadership in the Bohlabela District of Mpumalanga: Challenges and strategies. Unpublished Masters Dissertation. University of South Africa.

Moorosi, P., Fuller, K. \& Reilly, E. (2018). Leadership and Intersectionality: Constructions of Successful Leadership among Black Women School Principals in Three Different Contexts. Management in Education, 32(4). https://doi.org/10.1177/0892020618791006

Morgan, M. (2020). Black Women in Leadership: The Complexity of Intersectionality. The Third International Conference on Gender Research. University of Reading, Britain.

Msila, V. (2008). Ubuntu and School Leadership. Journal of Education, 44: 67- 84.

Myeza, A. April, K. (2021). Atypical Black Leader Emergence: South African Self-perceptions. Frontiers in Psychology, 12. https://doi.org/1.33/fpsyg.221.62643 

11(1)

Ndlovu, T. \& Proches, C.G. (2019). Leadership Challenges Facing Female School Principals in the Durban INK area. Gender \& Behaviour, 17(2), 12846-12858.

Ndebele, C. (2018). Gender and School leadership: Breaking the Glass Ceiling in South Africa. Generos, 7(2). https://doi.org/10.17583/generos.2018.2438

Palinkas, L. A., Horwitz, S.M., Green, C. A., Wisdom, J.P., Duan, N., \& Hoagwood, K. (2015). Purposeful Sampling for Qualitative Data Collection and Analysis in Mixed Method Implementation Research. Administration and Policy in Mental Health, 42(5), 533-544. https://doi.org/10.1007/s10488-013-0528-y

Phendla, T.S. (2021). "Metaphors of Leadership, Metaphors of Hope...Life Stories of Black Women Leaders in South Africa". African Journal of Transformation 1(1), 23-30.

Phakeng, M. (2015). Leadership: The Invisibility of African Women and the Masculinity of Power. South African Journal of Science. 2015, 111(11/12), Art. \#a0126, 2 pages. http://dx.doi.org/10.17159/sajs.2015/ a0126

Pounder, J.S. \& Coleman, M. (2002). Women - Better Leaders than Men? In General and Educational Management it still "all depends". Leadership \& Organisation Development Journal, 23(3): 122-133. https://doi10.1108/01437730210424066

Rosser-Mims, D. (2010). Black Feminism, An Epistemological Framework for Exploring How Race and gender Impact Black Women's Leadership Development Advancing Women in Leadership Journal, 30 (15). http://advancingwomen.com/awl/awl_wordpress/

Rossete, A.S. \& Livingston, R.W. (2012). Failure is not an Option for Black Women: Effects of Organizational Performance on Leaders with single Versus Dual-subordinate Identities. Journal of Experimental Social Psychology, 4 (5), 1162-1167. https://doi.org/10.1016/j.jesp.2012.05.002 Shanmugam, M., Amaratunga, R.D.G. \& Haigh, R.P. (2007). Leadership Styles: Gender Similarities, Differences and Perceptions. $7^{\text {th }}$ International Postgraduate Research Conference in the Built and Human Environment, $28^{\text {th }}-29^{\text {th }}$ March 2007, Salford Quays, United Kingdom.

Schniedewind, N. (1987). Feminist Values: Guidelines for Teaching Methodology in Women's Studies. In I. Shor (Ed.), Freire for the Classroom: A Sourcebook for Liberatory Teaching, pp.170-179. Portsmouth: Heinemann. 


\section{Msila-Black Women School Leaders}

Sylvester, C.M. (2019). Feminism and School Leadership: A Qualitative Study Utilizing Effective Women Principals' Self-Perceptions to Determine What to Determine What Makes Them Successful. PhD dissertation. University of Loyola. https://ecommons.luc.edu/luc_diss/3372

Unterhalter, E. (1990). On Women's Education in South Africa. Review of African Political Economy, 48: 66-75.

Wilcox, C. (1990). Black Women and Feminism. Women and Politics, 10(4), 65-68. https://doi.org/10.1300/J014v10n03_03

Wong, L.P. (2008). Data analysis in qualitative research: A brief guide to using Nvivo. Malaysian Family Physician, 3(1), 14-20.

Wood, H.J. (2019). Gender Inequality: The problem of Harmful, Patriarchal, Traditional and Cultural Gender Practices in the Church. Theological Studies, 76(1). https://doi.org/10.4102/hts.v75i1.5177

Zenger, J. \& Folkman, J. (2012). Are Women Better Leaders Than Men? Harvard Business Review. [Online] Available at: https://hbr.org/2012/03/a-study-in-leadership-women-do

Vuyisile Msila University of South Africa (South Africa) ORCID ID: https://orcid.org/0000-0002-8875-0644

Contact Address: msilavt@unisa.ac.za 